\title{
Exchange rate volatility and export growth in India: An ARDL bounds testing approach
}

\author{
P. Srinivasan ${ }^{\mathrm{a}^{*}}$ and M. Kalaivani ${ }^{\mathrm{b}}$
}

${ }^{a}$ Department of Economics, Christ University, Hosur Road, Bangalore 560029, Karnataka, India ${ }^{b}$ Department of Economics, Periyar University, Salem-636 011, Tamil Nadu, India

\section{H R O N I C L E \\ A B S T R A C T}

Article history:

Received March 2, 2012

Received in Revised Format

April 1, 2013

Accepted April 2, 2013

Available online

April 42013

Keywords:

Exchange rate volatility

Real exports

India

ARDL-UECM

Cointegration

CUSUM

CUSUMQ

\begin{abstract}
This paper empirically investigates the impact of exchange rate volatility on the real exports in India using the ARDL bounds testing procedure proposed by Pesaran et al. (2001). Using annual time series data, the empirical analyses has been carried out for the period 1970 to 2011. The study results confirm that real exports are cointegrated with exchange rate volatility, real exchange rate, gross domestic product and foreign economic activity. Our findings indicate that the exchange rate volatility has significant negative impact on real exports both in the short-run and long-run, implying that higher exchange rate fluctuation tends to reduce real exports in India. Besides, the real exchange rate has negative short-run and positive long-run effects on real exports. The empirical results reveal that GDP has a positive and significant impact on India's real exports in the long-run, but the impact turns out to be insignificant in the short-run. In addition, the foreign economic activity exerts significant negative and positive impact on real exports in the short-run and long-run, respectively.
\end{abstract}

(C) 2013 Growing Science Ltd. All rights reserved.

\section{Introduction}

Exchange rate volatility is a crucial element that needs to be considered for developing countries that depend extensively on trade - the case of India. It has traditionally been argued that exchange rate volatility may hinder the flow of international trade centered on the notion that exchange rate volatility represents uncertainty and will impose costs on risk-averse commodity traders. Exchange rate volatility is often treated as a risk and an increase in volatility would raise cost for risk-averse traders and depress trade (Ethier, 1973). This is because the exchange rate is agreed on, at the time of the trade contract, but payment is not made until the future delivery actually takes place. If changes in exchange rates become unpredictable, this creates uncertainty about the profits to be made and, hence, reduces the benefits of international trade. Cote (1994) stressed that the assumption of risk aversion does not necessarily lead to a conclusion that exchange rate volatility diminishes the amount of trade. His argument is based on the consideration that an increase in risk (exchange rate volatility)

* Corresponding author. $+91-9611273853$

E-mail addresses: srinivasaneco@gmail.com (P. Srinivasan)

C 2013 Growing Science Ltd. All rights reserved.

doi: $10.5267 /$ j.dsl.2013.04.002 
has two effects, namely a substitution effect and an income effect, which work in opposite directions. The substitution effect implies that exchange rate volatility negatively affects an agent's trade activity and reduces the expected total utility of the activity. Consequently income effect takes place in such a way that additional resources might be devoted to the activity in order to compensate for that plunge. Hence, in order to avoid the possibility of a decline in their revenues, the more risk-averse traders are engaged in more export activities as risks increase. Besides, Broll and Eckwert (1999) and Franke, (1991) have argued for an 'option' framework where a firm's engaging in export trade is viewed as an option The 'option view' indicates that exchange rate volatility will increase the value of the export option, thereby stimulating a firm's production and international trade activity if the degree of relative risk-aversion is less than unity.

The Indian economy has gained considerable momentum over the last one decade, by achieving and sustaining an annual GDP growth rate of over 7 percent. This high growth rate can be in part attributed to the growing contribution of the export sector to the economy. The contribution to world exports has improved since the economic reforms of 1991. Between 1991 and 2009, India's share in world exports rose from 0.56 to 1.52 percent. As India has progressively moved towards becoming a more open economy, policies have evolved to support trade and increase the volume of exports. As manufactured exports form a sizeable share of India's total exports, the sector is of key importance to the economy. However, the average performance of the manufacturing sector (reflected by the considerably low share of its contribution to the GDP) has for long, been a cause of concern. In recent years, the Indian government has acknowledged the severity of this issue and taken an important policy initiative in 2011 by approving the New Manufacturing Policy. On the other side, the exchange rate volatility becomes a major concern that influences the Indian exports. The rationale of this article lies with the importance of how exports respond to exchange rate shocks in both the long-run and the short-run. The findings of this study immense helpful to policymakers in India to stabilize exchange rate policy to promote large balance of trade surpluses as a mechanism of exports enhancement and hence economic growth, both in the short-run and long-run.

In this backdrop, the present paper examines the impact of exchange rate volatility on the Indian export flows. The paper is structured as follows. Section-2 reviews the literature on exchange rate volatility and exports. Section-3 presents methodology of the study. The empirical results and discussion are provided in section- 4 and section-5 presents concluding remarks.

\section{Review of Literature}

Exchange rates across the world have fluctuated widely particularly after collapse of the Bretton woods system of fixed exchange rates. Since then, there has been extensive debate about impact of exchange rate volatility on international exports. A significant amount of literature investigates the impact of exchange rate volatility on exports across various countries. Hooper and Kohlhagen (1978) examined the effects of exchange rate uncertainty on the volume of trade among developed countries. They do not found any significant impact of exchange rate volatility on the volume of trade. Cushman (1983) found negative relation between exchange rate volatility and volume of trade in the developed countries. Akhtar and Hilton (1984) examined the bilateral trade between West Germany and US and found that the exchange rate volatility has a significant negative impact on the exports and imports of two countries. Bailey et al. (1986) investigated the effect of exchange rate volatility on export of leading OECD countries (Canada, France, Germany, Italy, Japan, UK and US). The study revealed that exchange rate volatility has positive effect both in long run and short run. The studies by Virmani (1991), Joshi and Little (1994) and Srinivasan (1998) observed a negative and significant relationship between the real exchange rate and merchandise aggregate exports in India. Chowdhury (1993) investigated the impact of exchange rate volatility on the trade flows of the G-7 countries in context of a multivariate error-correction model. They found that the exchange rate volatility has a significant 
negative impact on the volume of exports in each of the G-7 countries. Besides, Frankel and Wei (1993) observed negative effects of volatility on trade flows with selected Asian countries.

Qian and Virangis (1994) examined the impact of exchange rate volatility on trade in six countries using ARCH model. The empirical results showed a negative link between exchange rate volatility and export volumes for Australia, Canada, and Japan and positive for United Kingdom, Sweden, and Netherlands. Fountas and Bredin (1998) showed that exchange rate volatility had short-run negative impact on real exports of Ireland to United Kingdom. Arize et al. (2000) investigated real exchange rate volatility on the exports of 13 less developed countries using Johansen's multivariate procedure and error correction model. Their study revealed a significant negative impact of volatility on export flows. Aristotelous (2001) also reported an insignificant relationship between exchange rate volatility on the UK-US exports. Using error correction model and cointegration approach, Vergil (2002) investigated the impact of real exchange rate volatility on export flows of Turkey to the US and three major trading partners in the European Union. The study showed that real exchange rate volatility was found to have negative relationship with exports both in long run and short run. Wang and Barrett (2002) found no significant relationship between expected exchange rate volatility and trade volumes in their investigation of Taiwan's exports to the United States. Besides, Baak et al. (2002) investigated the impact of exchange rate volatility on exports of four East Asian countries (Hong Kong, South Korea, Singapore and Thailand). Their results indicated that exchange rate volatility has negative impacts on exports in both the short run and long run. Srinivasan and Wallack (2003) and Veeramani (2008) found a negative and significant relationship between the real exchange rate and merchandise aggregate exports in India.

Akbostanci (2004) examined the short-run and long-run behaviors of the trade balance and real exchange rate using Turkish data. The study found that a real depreciation of the Turkish lira improved the Turkish trade balance in the long-run. Calderon (2004) investigated the impact of exchange rate variability on trade openness in a sample containing 79 countries and concluded that impact of volatility of real exchange rates was found to be meager. Using the ARDL bounds testing method to cointegration, De Vitta and Abbott (2004) observed that short-term volatility in exchange rate does not affect UK exports to the EU. However, there are significant and negative effects of volatility on UK exports to EU in the long-run. Mustafa and Nishat (2004) employed error correction model and cointegration approach to investigate the effect of exchange rate volatility on export growth between Pakistan and other leading trade partners such as SAARC, ASEAN, European and Asia Pacific regions. They found that exchange rate volatility had negative impact on export flows of Pakistan with United Kingdom, United States, Australia, Bangladesh and Singapore. While in the case of India and Pakistan, there exists only long-run impact and no short run relationship. In the case of New Zealand and Malaysia, no relationship was found. Kikuchi (2004) examined the impact of exchange rate volatility on exports in five East Asian Countries (Indonesia, Philippines, Singapore, South Korea and Thailand). The empirical results revealed negative relationship in Indonesia and positive relationship in Philippines, Singapore and Thailand. Besides, there is no relationship found in the case of Singapore and Thailand. Cameron et al (2005) further provided evidence for negative effects of exchange rate variability on Uganda's coffee exports. Todani and Munyama (2005) examined the relationship between exports and exchange rate volatility in South Africa. The study revealed a positive relationship between South African exports and exchange rate volatility in the both long- run and short-run. Rey (2006) investigated the impacts of nominal and real effective exchange rate volatility on exports of 6 Middle Eastern and North Africa (MENA) Countries to 15 member countries of the European countries (EU). The empirical results showed that MENA exports and exchange rate volatility are positively related in the case of Algeria, Egypt, Tunisia and Turkey in the long-run but negatively related with Israel and morocco. Further, the MENA exports and exchange rate volatility is positively related in the short-run for Morocco, Algeria, Tunisia and Turkey but negatively related for Egypt and Israel. 
Fang et al (2006) investigated the effect of exchange rate movement on exports of Eight Asian countries. The study revealed that real exchange rate depreciation has significant impact on exports for all countries except Singapore whereas exchange rate risk proves positive for Malaysia and Philippines but negative for Indonesia, Japan, Singapore, Taiwan and no effect for Korea and Thailand. Moccero and Winograd (2007) analyzed the link between real exchange volatility and exports in the case of Argentina. The study showed that decrease in real exchange volatility has a positive impact on exports to Brazil but a negative impact for the rest of world. Aliyu (2008) examined the impact of exchange rate volatility on non-oil export trade in Nigeria. The study observed that exchange rate volatility was found to have an adverse effect on non-oil exports in the long-run while in the short run, there is positive relationship. Chit, Rizov and Willenbockel (2008) examined the impact of real exchange rate volatility on real export of five emerging East Asian countries among themselves. The empirical results showed that real exchange rate volatility has negative impact on exports among emerging East Asian countries. Musonda (2008) showed negative short-run and long-run impacts of exchange rate volatility on non-traditional exports performance in Zambia. Sekantsi (2008) employed Autoregressive Distributed Lag (ARDL) approach and provided evidence that real exchange rate volatility exerts a significant and negative impact on South Africa's exports to the United States.

Hooy and Choong (2010) examined the impact of currency volatility on export demand within SAARC region, covering Bangladesh, India, Pakistan and Sri Lanka. The results showed that real exchange rate volatility had negative relationship with exports among the SAARC counterparts. Hosseini and Moghaddasi (2010) used the ARDL bound testing procedures and observed that there is no significant relationship between Iranian exports flows and exchange rate volatility. The study of Alam and Ahmad (2011) based on the ARDL analysis showed that real exports are cointegrated with volatility of real effective exchange rate. The study results revealed volatility of real effective exchange rate adversely affects the Pakistan's exports. Verena and Nawsheen (2011) empirically investigated the impact of real effective exchange rate volatility on the Mauritian export performance. The study results proved that exchange rate volatility has positive effects on exports in the short-run while in the long-run, the impact was negative. Bal (2012) examined the effects of exchange rate volatility on India's export and found no statistical and significant relationship between the exchange rate volatility and export of the country. But, the short term disequilibrium of exchange rate was negatively affects the export of the country. Dhasmana (2012) analysed the relationship between India's real exchange rate and its trade balance with her major trading partners using quarterly trade data for 15 countries. She found that real exchange rate volatility is negatively correlated with India's trade balance in the long run. Dolatti et al. (2012) investigated the effects of uncertainty and instability in real exchange rate on non-petroleum exports in Iran. The results indicated that uncertainty in real exchange rate had a negative effect on non-petroleum exports in long-term and short-term periods.

From the review of empirical literature on exports and exchange rate volatility, it is clear that the majority of the studies mainly focused on emerging economies like India. However, the studies pertaining to Indian context reveal mixed results. Hence, the effect of exchange rate variability on exports is still a debatable issue. The present study attempts to investigate the impact of exchange rate fluctuations on exports in India using the newly developed ARDL-Bounds testing approach. Unlike other cointegration techniques, the ARDL does not impose a restrictive assumption that all the variables under study must be integrated of the same order. Secondly, while other cointegration techniques are sensitive to the size of the sample, the ARDL test is suitable even if the sample size is small.

\section{Methodology}

The Autoregressive Distributed Lag (ARDL) bounds testing approach has been employed in this paper to examine the impact of exchange rate volatility on exports in India. The ARDL modeling 
approach was originally introduced by Pesaran and Shin (1999) and further extended by Pesaran et al (2001). This approach is based on the estimation of an Unrestricted Error Correction Model (UECM) which enjoys several advantages over the conventional type of cointegration techniques. First, it can be applied to a small sample size study Pesaran et al (2001) and therefore conducting bounds testing will be appropriate for the present study. Second, it estimates the short- and long-run components of the model simultaneously, removing problems associated with omitted variables and autocorrelation. Third, the standard Wald or F-statistics used in the bounds test has a non-standard distribution under the null hypothesis of no-cointegration relationship between the examined variables, irrespective whether the underlying variables are $\mathrm{I}(0), \mathrm{I}(1)$ or fractionally integrated. Fourth, this technique generally provides unbiased estimates of the long-run model and valid t-statistic even when some of the regressors are endogenous (Harris and Sollis, 2003). Inder (1993) and Pesaran and Pesaran (1997) have shown that the inclusion of the dynamics may correct the endogenity bias. Fifth, the short as well as long-run parameters of the model could be estimated simultaneously. Sixth, once the orders of the lags in the ARDL model have been appropriately selected, we can estimate the cointegration relationship using a simple Ordinary Least Square (OLS) method.

In view of the above advantages, ARDL-UECM used in the present study has the following form as expressed in Eq. (1):

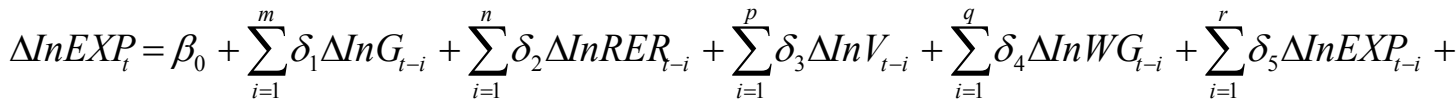

$$
\begin{aligned}
& \beta_{1} \operatorname{InEXP} P_{t-i}+\beta_{2} \operatorname{In} G_{t-i}+\beta_{3} \operatorname{InRER} R_{t-i}+\beta_{4} \operatorname{In} V_{t-i}+\beta_{5} \operatorname{In} W G_{t-i}+\varepsilon_{t},
\end{aligned}
$$

where, EXP represents India's real exports vis-a-vis its major export partners. RER is real exchange rate. G and WG represent gross domestic product of India and world GDP, respectively. V is the measure of real exchange rate volatility, $\mathrm{t}$ is the time dimension and $\Delta$ denotes a first difference operator; $\beta_{0}$ is an intercept and $\varepsilon_{\mathrm{t}}$ is a white noise error term. The home country GDP increases along the rise in its exports, so the expected sign is positive. The real exchange rate depreciation may lead to an increase in exports due to the relative price effect. Hence, the expected sign is positive. Besides, the relationship between the volatility of the real exchange rate and the real exports is ambiguous. One would expect increases in real GDP of trading partners to result in a greater volume of exports to those partners. Thus, it is expected that $\delta_{1}>0, \delta_{2}>0, \delta_{3}<0$ or $\delta_{3}>0$ and $\delta_{4}>0$.

The first step in the ARDL bounds testing approach is to estimate Equation (1) by ordinary least squares in order to test for existence of a long-run relationship among the variables by conducting an F-test for the joint significance of the coefficients of the lagged level variables, i.e., $\mathrm{H}_{0}: \delta_{1}=\delta_{2}=\delta_{3}=\delta_{4}=$ $\delta_{5}=0$ against the alternative $\mathrm{H}_{1}: \delta_{1} \neq \delta_{2} \neq \delta_{3} \neq \delta_{4} \neq \delta_{5} \neq 0$. Two sets of critical value bounds for the $\mathrm{F}$ statistic are generated by Pesaran et al (2001). If the computed F-statistic falls below the lower bound critical value, the null hypothesis of no-cointegration cannot be rejected. Contrary, if the computed Fstatistic lies above the upper bound critical value; the null hypothesis is rejected, implying that there is a long-run cointegration relationship amongst the variables in the model. Nevertheless, if the calculated value falls within the bounds, inference is inconclusive.

In the second step, once cointegration is established, the conditional ARDL long-run model for $\mathrm{EXP}_{t}$ can be estimated as:

$$
\operatorname{InEXP} P_{t}=\beta_{0}+\sum_{i=1}^{m} \delta_{1} \Delta \operatorname{In} G_{t-i}+\sum_{i=1}^{n} \delta_{2} \Delta \operatorname{InRER} R_{t-i}+\sum_{i=1}^{p} \delta_{3} \Delta \operatorname{In} V_{t-i}+\sum_{i=1}^{q} \delta_{4} \Delta \operatorname{InW} G_{t-i}+\sum_{i=1}^{r} \delta_{5} \Delta \operatorname{InEXP} P_{t-i}+\varepsilon_{t},
$$

where, all variables are previously defined. This involves selecting the orders of the ARDL (p, q) model using Akaike Information Criterion (AIC). In the third and final step, we obtain the short-run dynamic parameters by estimating an error correction model associated with the long-run estimates. This is specified as follows: 


$$
\operatorname{In} \Delta E X P_{t}=\beta_{0}+\sum_{i=1}^{m} \delta_{1} \Delta n G_{t-i}+\sum_{i=1}^{n} \delta_{2} \Delta n R E R_{t-i}+\sum_{i=1}^{p} \delta_{3} \Delta n V_{t-i}+\sum_{i=1}^{q} \delta_{4} \Delta n W G_{t-i}+\sum_{i=1}^{r} \delta_{5} \Delta n E X P_{t-i}+\varphi E C M_{t-1}+\varepsilon_{t},
$$

where, $\delta_{1}, \delta_{2}, \delta_{3}, \delta_{4}$ and $\delta_{5}$ are the short-run dynamic coefficients of the model's convergence to equilibrium and $\varphi$ is the speed of adjustment parameter and ECM is the error correction term that is derived from the estimated equilibrium relationship of Eq. (1).

The data set consists of observation on India's export of goods and services, real Gross Domestic Product, real exchange rate, real exchange rate volatility and the world GDP. The data on exports of goods (Merchandise exports on BoP basis) has been obtained from the Handbook of Statistics on the Indian Economy, Reserve Bank of India. Besides, the time series data on real GDP (Base Year 19992000) are obtained from the Central Statistical Organisation, Government of India. For the computation of real exchange rate, the study uses nominal exchange rate and Consumer Price Index of US and India that are obtained from International monetary fund. The formula used for the calculation of real exchange rate is $\log \left[\mathrm{NER} \times \mathrm{CPI}_{\mathrm{US}} / \mathrm{CPI}_{\mathrm{I}}\right]$, where, NER represents nominal exchange rate of the Indian rupee vis-à-vis US dollar. $\mathrm{CPI}_{\mathrm{US}}$ and $\mathrm{CPI}_{\mathrm{I}}$ denote Consumer Price Index of US and Consumer price index of India, respectively. Further, the real exchange rate volatility in the study is the time varying measure of volatility that is calculated through Moving Average Standard

Deviation (MASD). The formula is $\mathrm{V}_{\mathrm{t}}=\left[\frac{1}{2} \sum_{i=1}^{2}\left(L R E R_{t+i-1}-L_{R E R_{t+i-2}}\right)^{2}\right]^{1 / 2}$ where LRER is the log of real exchange rate and the moving average chosen is 2. The MASD has been chosen over the standard deviation measure as it is a time varying measure of volatility and given the low frequency data used, no GARCH effect was found. Finally, the World GDP (in value) has been collected from the World Development Report published by World Bank. The data set is annual and covers the period 1970 to 2011. It is appropriate to mention that, all econometric exercises are carried out by using EViews 7.1 and Microfit 4.1 software.

\section{Empirical Results and Discussions}

\subsection{Unit Root Test}

Prior to the application of the ARDL approach, it is appropriate that all the series be tested for stationarity or the 'same statistical property'- means the series have to be differenced or de-trended by the same number of times to render them stationary. The traditional approach of first differencing disregards potentially important equilibrium relationships among the levels of the series to which the hypotheses of economic theory usually apply (Engle and Granger, 1987).

\section{Table 1}

Augmented Dickey-Fuller Test Results

\begin{tabular}{lcc}
\hline Variables & Intercept & Decision \\
\hline Levels & & - \\
\hline EXP & 0.065 & $\mathrm{I}(0)$ \\
G & $2.975^{* *}$ & - \\
RER & -0.879 & - \\
V & -0.660 & - \\
WG & -2.220 & \\
\hline First Difference & & $\mathrm{I}(1)$ \\
\hline EXP & $-2.707^{* * *}$ & - \\
G & - & $\mathrm{I}(1)$ \\
RER & $-3.236^{* *}$ & $\mathrm{I}(1)$ \\
V & $-6.011^{*}$ & $\mathrm{I}(1)$ \\
WG & $-4.538^{*}$ & \\
\hline$*, * * * *)-$ indicates significance at the one, five and ten per cent level, respectively. Optimal lag length is determined by the Akaike Information Criterion
\end{tabular}


The use of non-stationary variables in the time series analysis leads to misleading inferences (Libanio, 2005). Besides, the unit root test is applied to check the order of integration and it is a crucial requirement for the existence of cointegration links (John, Nelson and Reetu, 2005). We use the Augmented Dicker Fuller (ADF) test to check for the unit root in each variable and thereby determine the order of integration. The unit root test results in the Table-1 confirms that all variables are I(1), except Gross Domestic Product (G) which is I(0). Since the variables are either I(0) or I(1), the ARDL process is used.

\subsection{Bounds F-test for Cointegration}

Table 2 presents the result of ARDL Bounds F-test for Cointegration relationship based on Eq. (1). The appropriate lag length was selected on the basis of Akaike Information Criterion (AIC) for the conditional ARDL-UECM.

Table 2

Results of Bounds Test Approach to Cointegration

\begin{tabular}{llc}
\hline \multirow{2}{*}{ Computed F-Statistic: $3.93 * *$} & \multicolumn{2}{c}{ Critical Value } \\
\cline { 2 - 3 } & Lower Bound & Upper Bound \\
\hline 1\% significance level & 3.41 & 4.68 \\
$5 \%$ significance level & 2.62 & 3.79 \\
$10 \%$ significance level & 2.26 & 3.35 \\
\hline ** indicates that computed statistic falls above the upper bonds value at five percent significance level. The Bounds critical values are obtained from \\
Pesaran, et al. (2001), Table: CI (iii) Case III: Unrestricted intercept and no trend $(\mathrm{k}=5)$.
\end{tabular}

The table result reveals that the computed F-statistic is obviously greater than the upper bound critical value of 3.93 at the five per cent significant level. Thus, the null hypothesis of no cointegration is rejected, indicating there is a stable long-run cointegration relationship among the variables. This implies that the considered variables are cointegrated among them i.e. these series cannot move too far away from each other or they cannot move independently of each other. Besides, the variables are cointegrated implies that there is some adjustment process in the short run, preventing the errors in the long run relationship from becoming larger and larger.

\subsection{Long-run Estimates of ADRL process}

Once the existence of cointegration relationship among the variables is confirmed, Eq. (2) was estimated for the long-run coefficients of the selected ARDL $(3,3,0,1,3)$ model based on the Akaike Information Criterion (AIC) and its results are presented in Table- $3^{1}$.

\section{Table 3}

Estimated Long-Run Coefficients Using the ARDL(3,3,0,1,3) Approach

\begin{tabular}{|c|c|c|c|}
\hline \multicolumn{4}{|c|}{ Dependent variable: $\ln E X P$} \\
\hline Regressor & Coefficient & t-statistic & Prob. value \\
\hline constant & -39.101 & $-5.1055^{*}$ & 0.000 \\
\hline $\ln G$ & 1.4042 & $5.2007^{*}$ & 0.000 \\
\hline $\operatorname{lnRER}$ & 1.4642 & $3.5961^{*}$ & 0.002 \\
\hline $\ln \mathrm{V}$ & -0.1276 & $-2.2417 * *$ & 0.035 \\
\hline $\operatorname{lnWG}$ & 1.4952 & $2.0543 * *$ & 0.046 \\
\hline
\end{tabular}

\footnotetext{
${ }^{1}$ The long run estimates and their standard errors were obtained using Microfit 4.0 (Refer to Pesaran and Pesaran, 1997). This uses Bewley's (1979) regression method to estimate the asymptotic standard errors and is equivalent to the so-called 'delta' method (Greene, 1993).
} 
The results indicate that the impact of exchange rate volatility on real exports is negative and significant at five percent level, which suggest that higher exchange rate fluctuation tends to reduce India's real exports in the long-run. This reveals that the risks associated with exchange rate variability discourage economic agents from trading across borders. Exchange rate volatility increases cost on risk-averse investors and therefore, respond by favoring to trade at the margin. As a consequence, the volume of exports from India to its trading partners reduces. Our findings support the notion that a raise in exchange rate risk leads to a reduction in the level of trade, which is consistent with Clark (1973), Baron (1976), Hooper and Kohlhagen (1978), Broll (1994), and Wolf (1995). It is worth noting that the estimated coefficient of real exchange rate is positive and statistically significant at one percent level, implying that the depreciation of currency is more effective in stimulating the growth of real exports in India. Moreover, the table results show that GDP exerts positive and significant effect on real exports in the long-run. Besides, the foreign economic activity (World GDP) plays a crucial factor in influencing real exports growth. The estimated coefficient of world GDP is positive and significant at one percent level, with real exports in the longrun. This suggests that the higher the income level of its trading partners leads to higher purchasing power of the country and thereby encourages more exports from India.

\subsection{Short-run Dynamics of ADRL process}

The results of short-run dynamic coefficients associated with the long-run relationships obtained from the ARDL-ECM equation (3) are presented in Table-4. The optimal lag length for the selected error correction representation of the ARDL $(3,3,0,1,3)$ model is determined by the Akaike Information Criterion (AIC).

\section{Table 4}

Error Correction Representation for the Selected ARDL $(3,3,0,1,3)$ Model

\begin{tabular}{|c|c|c|c|}
\hline \multirow{2}{*}{ Regressor } & \multicolumn{3}{|c|}{ Dependent variable: $\Delta \ln \mathrm{EXP}$} \\
\hline & Coefficient & t-statistic & Prob. value \\
\hline constant & -17.951 & $-3.692 *$ & 0.001 \\
\hline$\Delta \operatorname{lnEXP} P_{t-1}$ & 0.2911 & $1.808 * * *$ & 0.083 \\
\hline$\Delta \operatorname{lnEXP} \mathrm{t}_{\mathrm{t}-2}$ & 0.5738 & $3.322 *$ & 0.003 \\
\hline$\Delta \operatorname{lnRER} R_{t}$ & 0.1527 & 0.639 & 0.528 \\
\hline$\Delta \operatorname{lnRER}{ }_{\mathrm{t}-1}$ & -0.9912 & $-3.913^{*}$ & 0.001 \\
\hline$\Delta \operatorname{lnRER}{ }_{\mathrm{t}-2}$ & -0.5400 & $-2.148 * *$ & 0.041 \\
\hline$\Delta \ln V_{\mathrm{t}}$ & -0.0586 & $-2.868^{*}$ & 0.008 \\
\hline$\Delta \ln G_{t}$ & 0.1848 & 0.578 & 0.568 \\
\hline$\Delta \ln \mathrm{WG}_{\mathrm{t}}$ & -1.9861 & $-1.949 * * *$ & 0.062 \\
\hline$\Delta \ln \mathrm{WG}_{\mathrm{t}-1}$ & -2.2749 & $-2.844^{*}$ & 0.009 \\
\hline$\Delta \ln W G_{t-2}$ & -1.6649 & $-1.706^{* * *}$ & 0.093 \\
\hline $\mathrm{ecm}_{\mathrm{t}-1}$ & -0.4590 & $-3.285^{*}$ & 0.003 \\
\hline \multicolumn{4}{|c|}{ ecm $=\operatorname{lnEXP}-1.4642 * \operatorname{lnRER}+0.12766 * \ln V-1.4042 * \ln \mathrm{g}-1.4952 * \ln \mathrm{WG}+39.1014 * \mathrm{C}$} \\
\hline \multirow{3}{*}{\multicolumn{4}{|c|}{$\begin{array}{ll}\mathrm{R}^{2}=0.67604 & \mathrm{AIC}=45.5360 \\
\text { F-stat. }(11,26)=4.3633(0.001) & \mathrm{SBC}=33.2541 \\
\mathrm{D}-\mathrm{W} \text { statistic }=2.0152 & \\
\end{array}$}} \\
\hline & & & \\
\hline & & & \\
\hline \multicolumn{4}{|l|}{ Short-run Diagnostic Tests } \\
\hline Heteroscedasticity Test $\left(\chi^{2}\right)$ & \multicolumn{3}{|l|}{$=0.4607(0.460)$} \\
\hline Functional Form Test $\left(\chi^{2}\right)$ & \multicolumn{3}{|l|}{$=0.2284(0.663)$} \\
\hline
\end{tabular}

The table result reveals that the estimated error correction coefficient is negative and significant at one percent level ensuring that the adjustment process from the short-run deviation is quite moderate. More precisely, it indicates that 46 percent of the disequilibrium in real exports from the previous period's shock will be converges back to the long-run equilibrium in the current period. The empirical results indicate that the impact of exchange rate volatility on real exports is negative and 
significant, implying that higher exchange rate fluctuation tends to reduce Indian real exports in the short-run. One possible explanation for the fall in the volume of exports is the absence of hedging opportunities which cause risk-averse profit maximisation firms to reduce their exports in the face of high uncertainty. Moreover, the estimated coefficient of GDP exerts positive but insignificant effect on real exports in the short-run. The real exchange rate has negative and significant impact on real exports in the short-run, implying that the depreciation adversely affects the real exports in India. In contrast, the foreign economic activity has negative and significant impact on real exports in the short-run. This shows that the higher economic activity of importing countries leads to decrease in the volume of India's real exports.

\subsection{Stability of the ARDL process}

Finally, we examine the stability of the long-run coefficients together with the short-run dynamics by applying the CUSUM (Cumulative Sum of Recursive Residuals) and CUSUMSQ (Cumulative Sum of Squares of Recursive Residuals) plots (Brown et al. 1975). The CUSUM and CUSUMSQ plots for the estimated model are shown in Figure 1. If the plots of the CUSUM and CUSUMSQ statistics stay within the critical bounds of five per cent level of significance, the null hypothesis of all coefficients in the given regression are stable and cannot be rejected. Examination of plots in Figure-1 shows that CUSUM and CUSUMSQ statistics are well within the 5\% critical bounds implying that short run and long run coefficients in the ARDL-Error Correction Model are stable.

\section{Conclusion}

This paper empirically investigates the impact of exchange rate volatility on the real exports in India using the ARDL bounds testing procedure proposed by Pesaran, Shin and Smith (2001). Using annual time series data, the empirical analyses has been carried out for the period 1970 to 2011. The study results confirm that real exports are cointegrated with exchange rate volatility, real exchange rate, gross domestic product and foreign economic activity. Our findings indicate that the exchange rate volatility has significant negative impact on real exports both in the short-run and long-run, implying that higher exchange rate fluctuation tends to reduce real exports in India. Besides, the real exchange rate has a positive and significant long-run impact on real exports, which confirms that the depreciation of currency is more effective in stimulating the growth of India's real exports in the long-run. However, the impact of real exchange rate turns out to be negative and significant in the short-run, implying that the depreciation adversely affects the real exports in India. Moreover, the empirical results reveal that GDP has a positive and significant impact on India's real exports in the long-run, but the impact turns out to be insignificant in the short-run. In addition, the foreign economic activity exerts significant negative and positive impact on real exports in the short-run and long-run, respectively.

The present study recommends that the Reserve Bank of India (RBI) should pursue sustainable and stable exchange rate policy measures to promote greater exchange rate stability that would help to enhance the real exports of the economy. Most importantly, the policy makers in India should consider both the existence and the degree of exchange rate volatility while implementing trade and exchange rate policies for the growth of exports demand. Moreover, the study strongly recommends that RBI intervention should be needed to take control over depreciation of rupee in the short-run that adversely affects the real exports. This is due to the fact that for many Indian exporters, the rise in import costs of raw material offsets any export gains from the depreciating rupee. Further, the study insists on the need for a foreign trade policy that is in tune with the changed realities of the world economic activity in the short-run due to the alarming global economic crisis. 
Plot of Cumulative Sum of Recursive Residuals

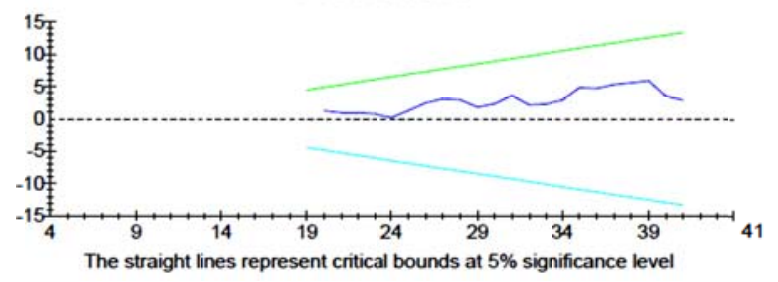

Plot of Cumulative Sum of Squares of Recursive Residuals

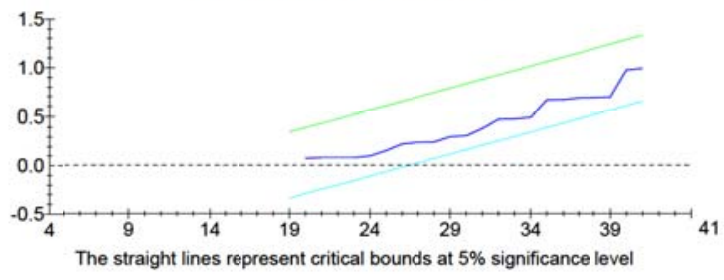

Fig. 1. The changes of cumulative sum of recursive as well as sum of recursive residuals

\section{References}

Akbostanci, E. (2004). Dynamics of the trade balance: The Turkish J-curve. Emerging Markets Finance and Trade, 40, 57-73.

Akhtar, M., \& Hilton, R. S., (1984). Effects of Exchange Rate Uncertainty on German and U.S. Trade. Federal Reserve Bank of New York Quarterly Review, 9, 7-16.

Alam, S., \& Ahmad, Q. M. (2011). Exchange Rate Volatility and Pakistan's Bilateral Imports from Major Sources: An Application of ARDL Approach. International Journal of Economics and Finance, 3, 245-254.

Aliyu S. (2008). Exchange Rate Volatility and Export Trade in Nigeria: An Empirical Investigation. MPRA Paper No. 13490, http://mpra.ub.uni-muenchen.de/13490/

Aristotelous, K. (2001). Exchange-rate volatility, exchange-rate regime, and trade volume: evidence from the UK-US export function (1889-1999). Economic Letters, 72, 87-94.

Arize, A. C., Osang, T., \& Slottje, D. J. (2000). Exchange-rate volatility and foreign trade: evidence from thirteen LDCs. Journal of Business \& Economic Statistics, 18, 10-17.

Baak, S., Al-Mahmood, A., \& Vixathep, S. (2002). Exchange Rate Volatility and Exports from East Asian Countries to Japan and U.S. http://www.karyiuwong.com/confer/seoul02/papers/baak.pdf

Bailey, M. J., Tavlas, G. S., \& Ulan, M. (1986). Exchange-rate variability and trade performance: evidence for the big seven industrial countries. Weltwirtschaftliches Archiv, 122, 466-477.

Bal, D. (2012). Exchange Rate Volatility and Its Effect on Export of India: An Empirical Analysis. The Indian Journal of Economics, 367, 68-79.

Baron, D. P. (1976). Fluctuating exchange rates and the pricing of exports. Economic Inquiry, 14, 425-438.

Bewley, R. A. (1979). The Direct Estimation of the Equilibrium Response in a Linear Model. Economics Letters, 3, 357-361.

Broll, U. (1994). Foreign production and forward markets. Australian Economic Papers, 33, 1-6.

Broll, U., \& Eckwert, B. (1999). Exchange rate volatility and international trade. Southern Economic Journal, 66, 178-185.

Brown R. L., Durbin J., \& Evans J. M. (1975). Techniques for Testing the Constancy of Regression Relationships over Time. Journal of the Royal Statistical Society, 37, pp.149-163.

Calderon, C. (2004). Trade Openness and Real Exchange Rate Volatility: Panel Data Evidence. Working paper No. 294, Central Bank of Chile.

Cameron, S., Kihangire, D., \& Potts, D. (2005). Has Exchange Rate Volatility Reduced Ugandan Coffee Export Earnings? Working paper, Bradford Centre for International Development (BCID), University of Bradford, Bradford, BD7-1DP, U.K.

Chit, M., Rizov, M., \& Willenbockel, D. (2008). Exchange rate volatility and exports: New empirical evidence from the emerging East Asian Economies. Middlesex University Economics and Statistics Discussion Paper No. 127, Middlesex University. 
Chowdhury, A. R. (1993). Does exchange rate volatility depress trade flows? Evidence from error correction models. The Review of Economics and Statistics, 76, 700-706.

Clark, P. B. (1973). Uncertainty, Exchange risk, and the level of International trade. Western Economic Journal, 11, 302-313.

Cote, A. (1994). Exchange rate volatility and trade: A survey. Working Paper 94-5, Bank of Canada.

Cushman, D. O. (1988). U.S bilateral trade flows and exchange risk during the floating period. Journal of International Economics, 24, 17-30.

De Vita, G., \& Abbott, A., (2004). The impact of exchange rate volatility on UK exports to EU countries. Scottish Journal of Political Economy, 51, 62-81.

Dhasmana, A. (2012). India's Real Exchange Rate and Trade Balance: Fresh Empirical Evidence. IIM Bangalore Research Paper No. 373, Indian Institute of Management (IIMB), Bangalore.

Dolatti, M., Eskandarpour, B., Abdi, B., and Mousavi, N. (2012). The Effect of Real Exchange Rate instability on Non-Petroleum Exports in Iran. Journal of Basic and Applied Scientific Research, 2, 6954-6961.

Engle, R. F., \& Granger, C. W. J. (1987). Cointegration and Error-Correction, Representation, Estimation, and Testing. Econometrica, 55, 251-276.

Ethier, W. (1973). International trade and the forward exchange market. American Economic Review, 63, 494-503.

Fang, W., Lai, Y., \& Miller, S. (2006). Export Promotion through Exchange Rate Changes: Exchange Rate Depreciation or Stabilization? Southern Economic Journal, 72, 611-626.

Fountas, S., \& Bredin, D. (1998). Exchange rate volatility and exports: The case of Ireland. Applied Economics Letters, 5, 301-304.

Franke, G. (1991). Exchange rate volatility and international trading strategy. Journal of International Money and Finance, 10, 292-307.

Frankel, J. A., \& Wei, S-J. (1993). Trade Blocs and Currency Blocs. NBER Working Paper no. 4335, National Bureau of Economic Research, Cambridge, MA.

Greene, W. H. (1993). Econometric Analysis. New York: Macmillan.

Harris, R., \& Sollis R. (2003). Applied Time Series Modelling and Forecasting. West Sussex: Wiley.

Hooper, P., \& Kohlhagen, S. (1978). The effect of exchange rate uncertainty on the price and volume of international trade. Journal of International Economics, 8, 483-511.

Hooy, C-W., \& Choong C-K., (2010). The Impact of Exchange Rate Volatility on World and Intratrade Flows of SAARC Countries. Indian Economic Review, 45, 67-86.

Hosseini, M. R., \& Moghaddasi, R. (2010). Exchange rate volatility and Iranian export. World Applied Sciences Journal, 9, 499-508.

Inder, B. (1993). Estimating long-run relationships in economics: A comparison of different approaches. Journal of Econometrics, 57, 53-68.

John, G., Nelson, P., \& Reetu, V. (2005). Unit Root Tests and Structural Breaks: A Survey with Applications. Revista De Metodos Cuantitativos Parala Economia Y La Empresa, 3, 63-79.

Joshi, V., \& Little, I. M. D. (1994). India: Macroeconomics and Political Economy, 1964- 1991. Oxford University Press, New Delhi.

Kikuchi, T., (2004). The impact of exchange rate volatility on bilateral exports in East Asian countries. MSc Thesis Graduate School of Systems and Information Engineering, University of Tsukuba.

Libanio, G. A. (2005). Unit roots in macroeconomic time series: theory, implications and evidence. Nova Economia Belo Horizonte, 15, 145-176.

Moccero, D. N., \& Winograd, C. (2007). Real exchange rate volatility and exports: Argentine perspectives. Working paper, Evry and Paris School of Economics (PSE - ENS), University of Paris.

Musonda, A. (2008). Exchange rate volatility and nontraditional export performance: Zambia, 19651999. AERC Research Paper 185, http://www.aercafrica.org/documents/RP185.pdf 
Mustafa, K., \& Nishat, M. (2004). Volatility of Exchange Rate and Export Growth in Pakistan: The Structure and Interdependence in Regional Markets. The Pakistan Development Review, 43, 813828.

Pesaran, M. H., \& Shin, Y. (1999). An Autoregressive Distributed Lag Modeling Approach to Cointegration Analysis. in Storm, S. (Ed). Econometrics and Economic Theory in the $20^{\text {th }}$ Century, The Ragnar Frish Centennial Symposium, Cambridge University Press: Cambridge.

Pesaran, M. H., Shin, Y., \& Smith, R. J. (2001). Bound Testing Approaches to the Analysis of Level Relationships. Journal of Applied Econometrics, 16, 289-326.

Peseran, M. H., \& Peseran, B. (1997). Working with Microfit 4.0. Interactive Econometric Analysis: Oxford University Press.

Qian, Y., \& Varangis, P. (1994). Does exchange rate volatility hinder export growth? Empirical Economics, 19, 371-396.

Rey, S. (2006). Effective Exchange Rate Volatility and MENA countries Exports to the EU. Journal of Economic Development, 31, pp.23-54.

Sekantsi, L., (2008). The impact of real exchange rate volatility on South African exports to the United States: A bounds test approach. mimeo.

Srinivasan, T. N. (1998). India's Export Performance: A Comparative Analysis. in I. J. Ahluwalia and I. M. D. Little (eds), Indias Economic Reforms and Development: Essays for Manmohan Singh, Oxford University Press, New Delhi.

Srinivasan, T. N., \& Wallack, J. (2003). Export Performance and the Real Effective Exchange Rate. in Reforming India's External, Financial, and Fiscal Policies by A.O. Krueger and S.Z. Chinoy, Eds., Stanford: Stanford University Press.

Todani, K. R., \& Munyama, T. V. (2005). Exchange rate volatility and exports in South Africa. manuscript available online at Trade and Industries Policy Strategies website: http://www.tips.org.za/files/773.pdf.

Veeramani, C. (2008). Impact of Exchange Rate Appreciation on Indias Exports. Economic and Political Weekly, 43, 10-14.

Verena, T., \& Nawsheen, E. (2011). Does exchange rate volatility harm export? Evidence from Mauritius. Journal of Emerging Trends in Economics and Management Sciences, 2, 146-155.

Vergil, H. (2002). Exchange rate volatility in Turkey and its effects on trade flows. Journal of Economic and Social Research, 4, 83-99.

Virmani, A. (1991). Demand and Supply Factors in Indias Trade. Economic and Political Weekly, 26, 309-314.

Wang, K. L., \& Barrett, C. B. (2002). A New Look at the Trade Volume Effects of Real Exchange Rate Risk. Cornell University Department of Applied Economics and Management Working Paper, No. WP 2002-41.

Wolf, A. (1995). Import and hedging uncertainty in international trade. Journal of Futures Markets, $15,101-110$. 